\title{
Expression of Nitrite Transporter Gene to Increase Nitrate Absoprtion in Rice Plant (Oryza Sativa Cv Nipponbare) as Sole Nitrogen Source
}

\author{
Sustiprijatno
}

\begin{abstract}
Incorporated of CsNitr1-L-transgene in rice plant was showed to active and transport $\mathrm{NO}_{2}^{-}$from cytosol into chloroplast. With a PCR method screening of CsNitr1-L gene were confirmed which the CsNitr1-L-transgene have amplification band, while the plant were not contained CsNitr1-L gene, there are no amplification band. Some strain were obtained and got a seeds. Almost CsNitr1-L-transgene was raising in all parameter test, such as plant height, tillers number, respectively. The accumulation of $\mathrm{NO}_{2}^{-}$in the leaves of CsNitr1-L-transgene was lower compared with wild type. CsNitr1-L is a cucumber $\mathrm{NO}_{2}^{-}$-transporter gene that located in chloroplast membrane have been transformed into japonica rice cv. Nipponbare. A series experiments was carried out to understand the expression- CsNitr1-L-transgenic rice. The seeds were cultivated to observe the activity of CsNitr1-L-transgene with medium containing $\mathrm{NO}_{3}^{-}$or $\mathrm{NO}_{2}^{-}$as inducer. Agronomical test, like tillers number and plant height were observed and compare with non CsNitr1-L-transgenic rice. While the $\mathrm{NO}_{2}^{-}$content in leaves were analyzed with capillary electrophoresis method.
\end{abstract}

Index Terms: Nitrite Transporter, rice, Transgenic, Nitrate, Nitrite.

\section{INTRODUCTION}

The importance of nitrogen in crop production has been documented well. However, a better understanding of several aspects of nitrogen metabolism is needed to make more efficient use of fertilizer nitrogen in crop production, and yet have a minimal impact on the environment. Usually, the inefficiency of nitrogen losses in application are caused by dentrification, leaching and ammonia volatilization [1]-[2].

The utilization of nitrogen in almost crop plants are use ammonium or nitrate and mixture as nitrogen sources. Based on this utilization, there are plants that having to like ammonium, such rice plant, Arabidopsis, and white spruce. While cucumber is prefer to nitrate as nitrogen sources. The while in the aerobic agriculture field, nitrate is major form which the mean soil solution concentration of $\mathrm{NO}_{3}{ }^{-}$is around $6.0 \mathrm{mM}$ compared with $0.77 \mathrm{mM}$ for $\mathrm{NH}_{4}{ }^{+}$[3], however, the utilization of such nutrient is not maintained well. Therefore, in the modern agriculture system requirments of such nutrient was obtained by dependence upon the massive application of $\mathrm{N}$ fertilizer which approximately 85 million

Revised Manuscript Received on April 25, 2019.

Sustiprijatno, Indonesian Center for Agricultural Biotechnology and Genetic Resources Research and Development, Indonesian Agency for Agricultural Research and Development, Jalan Cimanggu, No. 3A, Bogor, Indonesia metric tons per annnum worldwide [4]. In the cultivation of rice, it can concume nitrogen about $10 \%$ of globally for different crops [5].

In the future, it is challenging to create the $\mathrm{NO}_{3}{ }^{-}$-use improvement by high assimilation of nitrate nitrogen. In the assimilation of higher plants, firstly nitrate reduces to nitrate by Nitrate Reductase (NR) in cytosol, then nitrite reduces to ammonium by Nitrite Reductase (NiR) in chloroplast [6].

Nitrite ion as intermediate product is toxic to plant cells [7]-[8]. It assumes that transports across the chloroplast inner envelope occurs by the transport of the protonated form of $\mathrm{NO}_{2}^{-}, \mathrm{HNO}_{2}$ [9], or by the uptake of the $\mathrm{NO}_{2}{ }^{-}$ion [10]-[11] Some studies was carried out that transporting is caused may be by a protein transporter for $\mathrm{NO}_{2}{ }^{-}$, However, knowledgement of this transporter is not understanding yet.

A nitrite transporter gene have been founded and cloned that localized on chloroplast envelope from cucumber plant, CsNitrl-L [12]. And it is used for transformation of rice plant by Agrobacterium tumefaciens infection method. Since cucumber plants is nitrate plant, but rice prefer to ammonium, we consider transgenic rice plant can utilized nitrate as well as use ammonium.

\section{MATERIALS AND METHOD}

Gene-transferring binary vector, $p I G 121 \mathrm{Hm}$, harboring genes for hygromycin resistance and intron GUS in the T-DNA region under the control of CaMV35S promotor was used as control (Fig.1). And replacing the GUS gene at XbaI-SacI site by cucumber nitrite transporter (CsNitrl) gene (Fig.2). Both vector, then introduced into Agrobacterium tumefaciens strain EHA 101 by electrophoration according to [13]-[14].

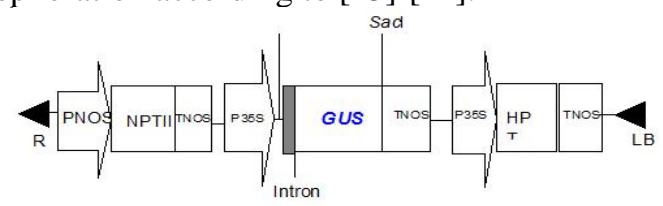

Fig.1: $p I G 121 H m:: G U S$ construct

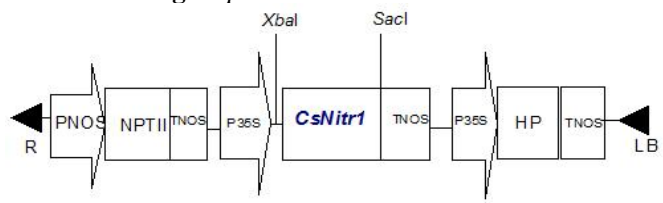

Fig. 2: pIG121Hm::CsNitr1-L construct

Mature seeds of Japonica rice cultivar Nipponbare were dehulled and sterilized by $70 \%$ ethanol for 1 minute, then by $50 \%$ Sodium hypochloride for 30 minutes. After rinsed with steril distilled water, the steril seeds were placed into 


\section{Expression of Nitrite Transporter Gene to Increase Nitrate Absoprtion in Rice Plant (Oryza Sativa Cv Nipponbare) as Sole Nitrogen Source}

N6-callus induction media and incubated at $28^{\circ} \mathrm{C}$ under continuous light.

At two weeks cultivation the calli derived from scutellum were sub cultured for 4 days and used as materials for transformation.

The rutine procedure for transformation of rice plants were carried out as according to [15]. The single colony of cell line from Agrobacterium containing both CsNitrl gene and GUS gene were suspended with AA-medium supplemented with $10 \mathrm{mg} / \mathrm{l}$ acetosyringone [15]. Freshly sub cultured embryogenic calli were submerged in that bacterial suspension for 3 minutes. Calli were then placed on to co-cultivated medium and incubated for two days in the dark condition. After washed with sterile water, which containing $500 \mathrm{mg} / \mathrm{L}$ carbenicillin, transgene-calli selected on selection medium containing Higromycin for two weeks at $28^{\circ} \mathrm{C}$ under continuous illumination. The selected-proliferate calli were then transferred onto regeneration medium and regenerate plants transferred onto root induction medium for stability of rooting. The plant-transgene were placed on the vermiculite and allowed to maintain in the green house until maturity and to get seeds.

Genomic DNA was isolated from the leaves of transgenic plants with ISOPLANT method from TAKARA, the manual were given by the company. Transgenic plants were initially screened by the polymerase chain reaction (PCR) analysis to confirm the insert of gene. Five hundred ng of DNA were amplified by which primer that used were:

\section{R: 5'-GAACCATGAGCTTGATG-3'}

\section{F: 5'-AGGGAATGGTTACCAT-3'}

To grow rice plant were cultivated hydroponically according standard procedure from Internatiomal Rice Research Institute, IRRI. Surface-sterilize rice seeds was by $70 \%$ ethanol for 1 minute and by $30 \%$ Sodium hypchloride for 1 hour. Then wash thoroughly with several changes of distile water and allow the seeds to soak at $38^{\circ} \mathrm{C}$ for 24 hours. The sterilized seeds were germinated into plate containing kimwipe paper with distile water as netral nutrition. Two days germinated plants were transfer into pot that containing Yoshida medium with $\mathrm{N}$-free. After two weeks old, seedlings of nearly uniform size were selected and transplanted in a pot that was filled with small stones containing medium with various nitrogen sources [15]. Renewal of culture solution was performed once a week and all cultivation were incubated on green house.

The accumulation of $\mathrm{NO}_{2}^{-}$and $\mathrm{NO}_{3}{ }^{-}$in the leaves were analyzed by capillary electrophoresis according to the procedure that given by [16]-[17]. a hundred mg fresh weight of leaves were grounded with $50 \mathrm{ul}$ of $0.1 \%$ SDS. After added with $500 \mathrm{ul}$ of chloroform, the extract were centrifuged at $18,000 \mathrm{x} g$ for $10 \mathrm{~min}$. The aquous layer of solution then used to determined $\mathrm{NO}_{2}{ }^{-}$and $\mathrm{NO}_{3}{ }^{-}$content.

Uptake of $\mathrm{NO}_{2}^{-}$and $\mathrm{NO}_{3}^{-}$were determined by following the depletion of $\mathrm{NO}_{2}{ }^{-}$and $\mathrm{NO}_{3}{ }^{-}$from the induction medium. The concentration of $\mathrm{NO}_{3}{ }^{-}$was assayed by a $\mathrm{NO}_{3}{ }^{-}$electrode meter (HORIBA-D231). While $\mathrm{NO}_{2}^{-}$concentration was measured by colorimetric method.

\section{RESULTS AND DISCUSSION}

Screening of CsNitrl-L gene was confirm by genomic PCR which transgene that contain insert gene are amplified with specific primer, CsNitr1-S-33-567R. As shown in the Fig. 3, CsNitrl-transgene have amplification band, while wild type there are no amplification.

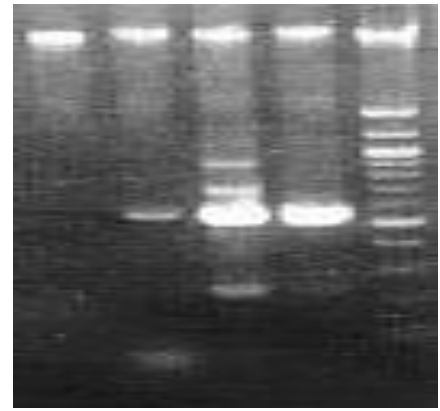

Fig. 3: Genomic DNA (500 ng) was used as template for PCR amplification of CsNitr1-L fragment. The reaction mixture $(10 \mu \mathrm{l})$ run in $1.5 \%$ agarose gel with DNAA size marker (M). Lane indicating wild type and number of strain (from left to right).

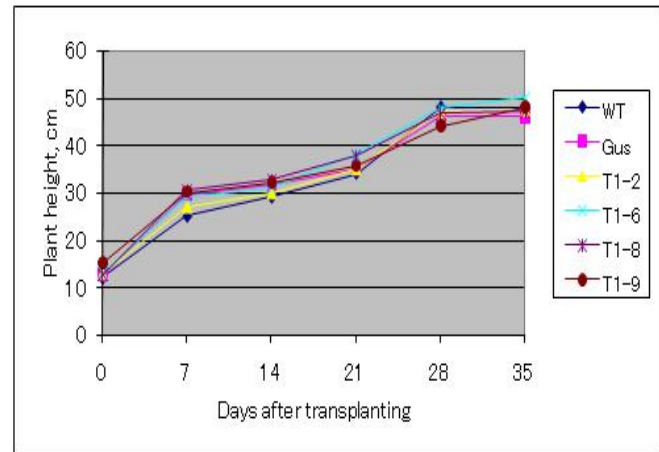

(a)

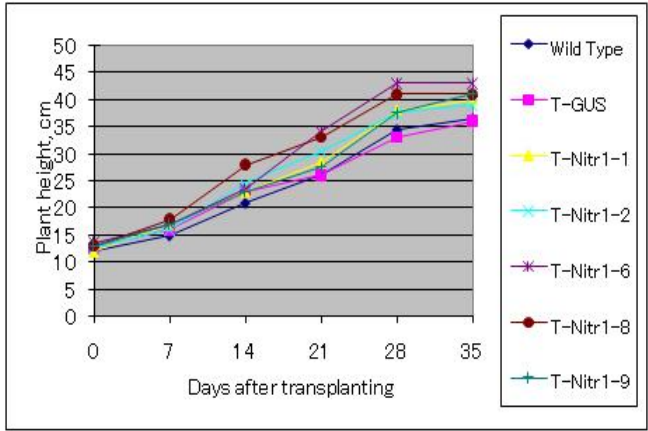

(b)

Fig. 4: Effect of CsNitr1-transgene on height of rice plant supplemented with $\mathrm{NO}_{3}{ }^{-}$(A) and $\mathrm{NH} 4+(\mathrm{B})$ as sole nitrogen source. Absis indicating days of transplanting and ordinate is plant height was measure in $\mathrm{cm}$.

When CsNitrl-transgenic rice cultivated on medium supplemented with $3 \mathrm{mM} \mathrm{NO}_{3}{ }^{-}$as sole nitrogen source, the plant height is more taller compare with wild type and GUS-transgenic rice (Fig.4a), but the plant height of CsNitrl-transgenic rice were as tall as wild type and $G U S$-transgenic rice when cultivated with $-\mathrm{NH}_{4}{ }^{+}$as sole nitrogen source (Fig.4b). 
The growth rate of CsNitrl-transgene show increasing when cultivated at 2 weeks (Fig. 5), but wild type or $G U S$-transgene was inhibited.

The tillers number of CsNitrl- trangenic rice is more active than wild type and GUS-transgene when cultivated on medium supplemented with $3 \mathrm{mM} \mathrm{NO}_{3}{ }^{-}$as sole nitrogen source (Fig. 6).

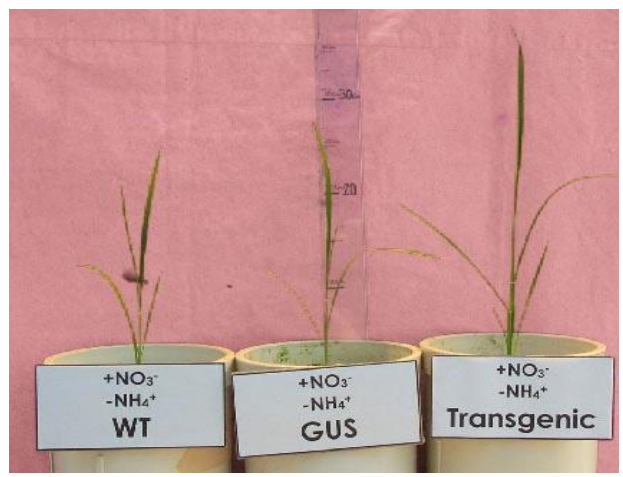

Fig. 5: Nitrate utilization of CsNitr1-transgenic rice supplemented with $\mathrm{NO}_{3}{ }^{-}$as sole nitrogen sources at 2 weeks.

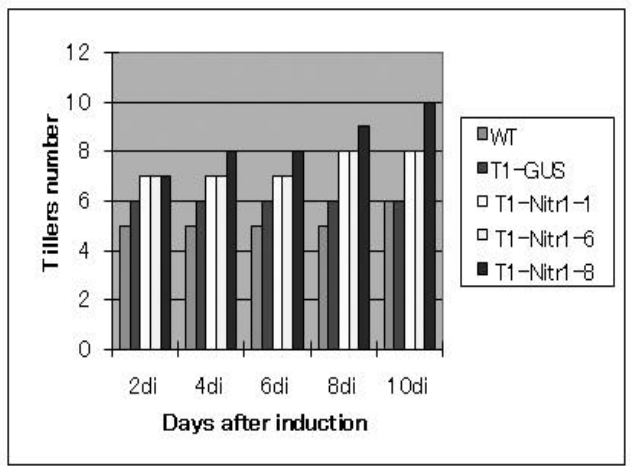

Fig. 6: Ability of tillers number on CsNitr1-transgene induced by NO3The plant were induced at 1 month old after transplanting.

The accumulation of $\mathrm{NO}_{2}^{-}$in $C s N i t r l$-transgenic-leaves were more less one forth than wild type (Fig. 7).

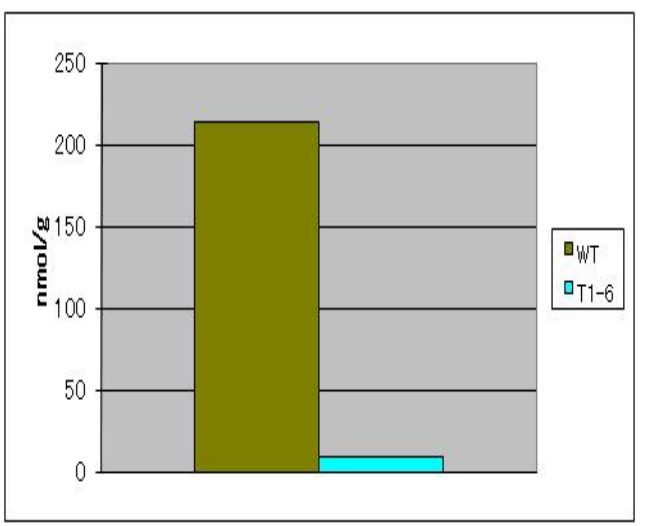

Fig.7: Accumulation of $\mathrm{NO}_{2}{ }^{-}$and $\mathrm{NO}_{3}{ }^{-}$concentration in CsNitr1-L transgene-leaves

\section{CONCLUSION}

Nitrate is one of major form of nitrogen which it taken up into the roots cells and can be stored temporarily in the vacuole. Some portion of them were assimilated both in the roots and leaves. One key of the primary assimilation product is nitrite, since its accumulation caused toxic to plant cells.
We considered that the accumulation can be lowered, when the nitrite in the cytosol can be transfer into chloroplast by nitrite transporter that localized in the chloroplast.

CsNitrl- $L$ was induced by present of $\mathrm{NO}_{3}{ }^{-}$, indicated that after $\mathrm{NO}_{3}{ }^{-}$ was assimilated and reduce to $\mathrm{NO}_{2}^{-}$, this intermediate product can be transport more in the CsNitr1-trangene in comparison with wild type and GUS-transgene.

The accumulation of $\mathrm{NO}_{2}^{-}$was less in CsNitrl-transgene than wild type indicated that some portion of $\mathrm{NO}_{2}^{-}$was transport into chloroplast suggested that nitrite transport activity of wild type was low comparing with CsNitrl-transgene. This mean that there are activation of $\mathrm{NO}_{2}{ }^{-}$transport in CsNitr1-transgene.

\section{REFERENCES}

1. S. K. De Datta. Principles and Practices of Rice Production. New York: John Wiley,1977.

2. D. S. Mikkelsen, S. K. De Datta and W. N. Obcemea. "Ammonia Volatilization Losses from Flooded Rice Soils 1." Soil Science Society of America Journal, vol. 42, no. 5, pp. 725-730, 1978

3. J. D. Wolt, Soil Solution Chemistry, New York: John wiley \& sons, 1994.

4. N. M. Crawford and A. D. Glass. Molecular and physiological aspects of nitrate uptake in plants. Trends in plant science, vol. 3, no. 10, pp. 389-395, 1988

5. N. K. Fageria, V. C. Baligar and C. A. Jones. Rice in Growth and mineral nutrition of field crops. New York: Marcel Dekker, Inc, 1977.

6. T. Hoff, H. N. Truong and M. Caboche. "The use of mutants and transgenic plants to study nitrate assimilation.” Plant, Cell \& Environment, vol. 17, no. 5, pp. 489-506, 1994.

7. O. L. Oke. "Nitrite toxicity to plants." Nature, vol. 212, art. no. 528, 1966.

8. H. W. Heldt. Plant Bichemsitry and Molecular Biology ;Nitrate assimilation. Britania Raya: Oxford University press, 1977.

9. U. Heber and P. Purczeld. "Substrate and product fluxes across the chloroplast envelope during bicarbonate and nitrite reduction." In Proceedings of the 4th International Congress on Photosynthesis, pp 107-118, 1978.

10. P. Brunswick and C. F. Cresswell. "Nitrite uptake into intact pea chloroplasts: I. Kinetics and relationship with nitrite assimilation." Plan physiology, vol. 86, no. 2, pp. 378-383. 1988

11. P. Brunswick and C. F. Cresswell. "Nitrite uptake into intact pea chloroplasts: II. Influence of electron transport regulators, uncouplers, ATPase and anion uptake inhibitors and protein binding reagents." Plant physiology, vol. 86, no. 2, pp. 384-389, 1988.

12. M. Sugiura, R. Kittaka, Y. Hatayama and M. Takahashi. "Characterization And Cdna Isolation Of A Nitrite Transporter Localized On The Chloroplast Envelopes." Plant and cell physiology, vol. 41, art. no. s90, 2000.

13. E. E. Hood, G. L. Helmer, R. T. Fraley and M. D. Chilton. "The hypervirulence of Agrobacterium tumefaciens A281 is encoded in a region of pTiBo542 outside of T-DNA." Journal of Bacteriology, vol. 168, no. 3, pp. 1291-1301, 1986.

14. J. Sambrook, E. F. Fritsch and T. Maniatis. Molecular cloning: A laboratory Manual, NY:Cold spring Harbor Laboratory Press, 1989.

15. S. Yoshida. "Routine procedure for growing rice plants in culture solution." Laboratory manual for physiological studies of rice, pp. 61-66, 1976.

16. H. Sasakawa and Y. Yamamoto. "Comparison of the uptake of nitrate and ammonium by rice seedlings: influences of light, temperature, oxygen concentration, exogenous sucrose, and metabolic inhibitors.” Plant Physiology, vol. 62, no. 4, pp. 665-669, 1978

17. K. Toriyama and K. Hinata. "Cell suspension and protoplast culture in rice.” Plant Science, vol. 41, no. 3, pp. 179-183, 1985. 